\title{
固体飛跡検出器の進歩についで
}

\author{
道 家 忠 義 \\ 東京大学原子核研究所
}

1960年代の初めに打ける Fleischer, Price, Walker による chemical etching 法の導入によって固体 飛跡検出器は一躍その応用範囲を広げ, 核物理学, 宇 宙物理学, 原子力工学, 地質学, 考古学等各方面に広 く利用されるようになった。これらの状況については 本誌に扮いて子数年前に坂上氏により総合解説がなさ れたが ${ }^{1)}$, その後も固体飛跡検出器の基礎, 応用両面 にわたる進歩は著しく，いまな挔衰えを知らないとい う現状である。ここでは主として前記総合解説以後の 進展の模様についてわたくし流にまとめてみたつるり であるが，その応用面については範囲があまりにも広 く筆者一人でそのすべてに触れることは不可能なので 筆者の関心のあるもののみに限ることとした。

\section{1. 飛跡生成の機構とその条件}

従来の固体飛跡検出器飞乱友跡生成の機構につ いては Fleischer, Price, Walker の主張する “ion explosion”説と Chadderton, Morgan, Torrens, Van Vliet らの唱えている “electron thermal spike” 説とが対立しているが22，いずれる無機結晶や無機物 質を対象として郝り, 固体飛跡検出器として広く利用 されている有機物質での飛跡生成の機構としては必ず 乙も適切とはいえない。最近はこのような立場から上

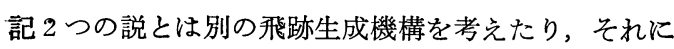
関連した実験を行なったりしている場合が多い。ここ ではまず飛跡生成のための criterion としてぞのよう な量が考兄られているかについて述べるとともに，有 機物質による陽子の検出や $\alpha$ 崩壊に伴う反跳核の検出 に関する新しい実験結果, 外的条件の飛跡生成に打よ ぼす影響，打よび新しい原理に基づく飛跡検出器等に ついて述べる。

$1 \cdot 1$ 飛跡生成のための criterion

固体飛跡検出器に重イオンの飛跡が作られるために は，重イオンの通路に沿って単位長さあたりにある一 定値以上のエネルギーが付与されねばならない。かか るしきい値としてどのような量をとるべきかは飛跡生 成の機構を知るらえにる，また応用的見地から考えて
も非常に重要なことである。初めはこのような量とし て単に検出器を構成する物質の阻止能を考劣ていた が，やがてそれは飛跡生成のためのよき criterion と はならないことがわかってきた。ついで Fleischer; Price, Walker, Hubbard は $\delta$ 線による二次電離は飛 跡生成に寄与せず, 重イオンの通路に沿った単位長さ あたりの生成イオン対数 $(d J / d x)$-primary specific ionization一のみがそれに関与すると考衣，飛跡生成 のしきい值が物質固有の量 $(d J / d x)_{\mathrm{erit}}$ として一義的 に表わしらるとして成功を収めた ${ }^{3)}$ 。そのさい，かれ らは $(d J / d x)$ として Bethe によって与えられた次 式を使用しだ)。

$$
\begin{aligned}
\frac{d J}{d x} & =\left(\alpha Z_{e}^{2} / I_{0} \beta^{2}\right)\left[\ln \left\{2 m c^{2} \beta^{2} /\left(1-\beta^{2}\right) I_{0}\right\}\right. \\
& \left.-\beta^{2}+3.04\right]
\end{aligned}
$$

ここで $Z_{e}$ は入射重荷電粒子の有効電荷, $\beta$ は粒子 の速度と光速 $c$ との比, $m$ は電子の質量, $I_{0}$ は物質 を構成する原子の外殼電子に対するイオン化エネルギ 一， $\alpha は$ 物質によってきまる定数である。また有効電 荷としては Heckman らの実験結果 ${ }^{5}$ 亿基ついて作ら れたつぎの経験式を使用している。

$$
Z_{e}=Z\left[1-\exp \left(1-125 \beta / Z^{2 / 3}\right)\right]
$$

ここで $Z$ は入射荷電粒子の核電荷である。

確かに(1)式によって定義される $(d J / d x)$ は飛跡生 成の条件を与えるためのよき criterion ではあるが, これにはつぎのような幾つかの欠点がある。すなわ ち, (1)式に和ける $\ln$ 内の最終項3.04は厳密には水素原 子に対してのみ使用しらる值であること, つぎに飛跡 生成のしきい値として $(d J / d x) \mathrm{crit}$ が物質固有の一定 值として与えられるためには polycarbonate や cellulose nitrate のような有機物質に対して $I_{0}$ として $2 \mathrm{eV}$ 值を使用しなければならない点である。有機物 質のイオン化ポテンシャルは $9 \sim 15 \mathrm{eVなるゆえ} 2 \mathrm{eV}$ ではイオン化は不可能である。したがって $I_{0}=2 \mathrm{eV}$ 使用は(1)式の内容からいって適切でない。また固体飛

\footnotetext{
$\uparrow$ Progress in Solid State Track Detector, Tadayoshi DokE: Institute for Nuclear Study, University of Tokyo, Tanashi-shi, Tokyo.
} 
跡検出器として広く使用されている有機物質の重イオ ンの通路に沿った放射線損傷を考えた場合， $\delta$ 線の効 果をすべて無視することはあまりにも不自然である。 むしろ，その通路に沿って物質に付与された単位質量 あたりのエネルギー（すなわち吸収線量）がある值を 越光た場合に etch されやすい飛跡が生成されると考 劣るべきで，そのためにはエネルギーの低い $\delta$ 線の寄 与は当然その吸収線量のなかに含まれるべきである。

以上のような Fleischer らの "primary specific ionization”に対し Katz, Kobetich は重イオンの通 路を中軸とした円筒を考えそその軸から $r$ だけ離れた 点に拈ける重イオンの $\delta$ 線によるエネルギー付与 $D_{r}$ を飛跡生成に関する最適の criterion と考皇た ${ }^{6}$ 。た とえば有機物質の場合， $D_{r}$ がある一定值を越えれば 重イオンの通路に沿った半径 $r$ なる円筒の内部はかな りの放射線損傷を受け細かい分子片が多数生成される ことになる。これらは損傷を受けていない親の高分子 に比べ溶解しやすいゆえ， $r$ として etching 用溶夜が 自由に出入できる程度の大きさ $r_{0}$ になれば，それを etching 可能な潜在飛跡とみなしてよいであろう。 Katz, Kobetich は Price, Walker の電子顕微鏡に よる実測結果 そ基づいて， $r_{0}=20 \AA$ と仮定しそこに 打ける $D_{20 \AA}$ を計算した。図 $1(\mathrm{a}),(\mathrm{b})$ はかくして求め

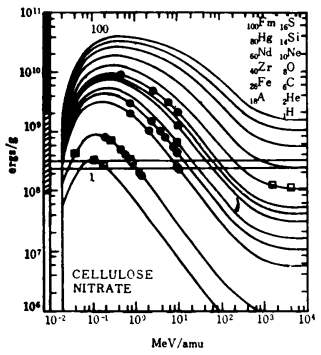

(a)

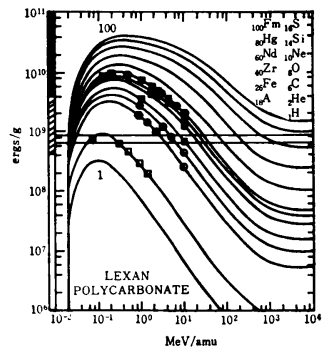

(b)
図 1 固体飛跡検出器における重イオンの nucleon 怙たりのエネルギーに対する $D_{20 \AA}$ の変化と その曲線上に示された飛跡生成の有無. は飛跡が検出された場合，○口は飛跡が検出 されなかった場合を示す。

a) cellulose nitrate,

b) Lexan (polycarbonate)

られた cellulose nitrate と polycarbonate そ抢ける 重イオンの核子あたりのエネルギーに対する $D_{20 \AA}$ の 変化である。四からわかるよらに飛跡の有無について はいずれもかなり明確なしきい值が存在する。しかも それらの值は $10^{6} \sim 10^{7} \mathrm{rad} て ゙, \gamma$ 線の照射により有効な 放射線損傷が起こり始める線量と一致する。またこの
程度の放射線照射を受けた有機物質の表面が etchant により侵食される速度は etching による飛跡の生長速 度とほぼ等しい87。このような重イオンの通路に沿っ た線量分布は飛跡生成の機構を理解するらえで非常に 有益であるが，その計算は煩さである。これに対しつ ぎに述べる Benton, Nix の提唱する! criterion ${ }^{8), 9)}$ は $\delta$ 線の寄与も考慮し，かつその計算も容易なのでよ り一般性があると思われる。

すなわち, Benton, Nixは $\delta$ 線のうち比較的エネル. ギーの低いるのは飛跡の生成に役立っていると考卉, 重イオンの通路に沿らエネルギー損失のうち一定のエ ネルギー $\omega_{0}$ 以上の $\delta$ 線の寄与を除いたもの，いわゆ る REL (restricted energy loss) を飛跡生成の有 無を判断するための criterion と考光た。かかるREL は次式から容易に求めることができる ${ }^{10}$ 。

$$
\begin{aligned}
& (d E / d x)_{\omega}<\omega_{0}=2 \pi n Z_{e}^{2} e^{4} / m c^{2} \beta^{2}\{\mathrm{ln} \\
& \left.\quad\left(2 m c^{2} \beta^{2} \gamma^{2} \omega_{0} / I^{2}\right)-\beta^{2}-2(C / Z)-\delta\right\}
\end{aligned}
$$

ここで, $n$ は阻止物質の電子密度, $\gamma=\left(1-\beta^{2}\right)^{-1 / 2}, I$ は 物質の平均励起エネルギー, $C / Z$ は内殼補正の項, $\delta$ は密度効果に対する補正項である。この式は $3 \mathrm{MeV} /$ nucleon までは一応満足な結果を与兄ているが，その エネルギー以下では近似が悪くなるので，そのエネル ギー領域では実測值に合うように種々のパラメーター を調整した半実験式から全阻止能 $(d E / d x)_{r}{ }^{8), 11)}$ を求 め，それからいわゆる“close collision”によるェネ ルギー損失 $(d E / d x)_{\omega>\omega_{0}}$ を差引くことにより $(d E /$ $d x)_{\omega<\omega_{0}}$ を求めている。そのさい, $(d E / d x)_{\omega}>\omega_{0}$ は 次式から得られたものを使用している。

$$
\begin{aligned}
& (d E / d x)_{\omega>\omega_{0}}=2 \pi n Z_{e}^{2} e^{4} / m c^{2} \beta^{2}\{1 \mathrm{ln} \\
& \left.\left(\omega_{\max } / \omega_{0}\right)-\beta^{2}\right\}
\end{aligned}
$$

ここで $\omega_{\max }=\left\{2 \beta^{2} /\left(1-\beta^{2}\right)\right\} m c^{2}$ である。四 $2(\mathrm{a}),(\mathrm{b})$ は cellulose nitrate $と$ polycarbonate の $\omega_{0}=1 \times 10^{3}$ $\mathrm{eV}$ を仮定した場合の各種重イオンに対する $R E L$ の エネルギー変化を示す。四から明らかなように 0.1 $\mathrm{MeV} /$ nucleon に打ける軽い粒子の実測点を除いてか なり明確な飛跡生成に関する $R E L$ の臨界値 (cellulose nitrate: $1.1 \times 10^{3} \mathrm{MeV} \cdot \mathrm{cm}^{2} / \mathrm{g}$, polycarbonate $3.3 \times 10^{3} \mathrm{MeV} \cdot \mathrm{cm}^{2} / \mathrm{g}$ ) が得られている。etchable な 潜在飛跡の幅は $100 \AA ̊$ 以下と考兄られるので，それと 上記の $(R E L)_{\mathrm{crit}}$ の值から飛跡内の臨界吸収線量の 下限を求めると cellulose nitrate に対して2.5 $510^{7}$ $\mathrm{rad}$ なる值が得られる。この值は前にも指摘したよう に $\beta$ 線等の照射で表面における etching の速度が急 速に増加し始めるところの線量とよく一致する。また $\omega_{0}=1 \mathrm{keV}$ といら值もその実効飛程から考えて無理の 


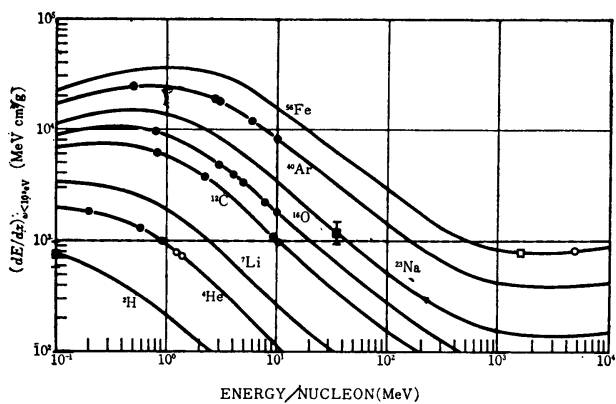

(a)

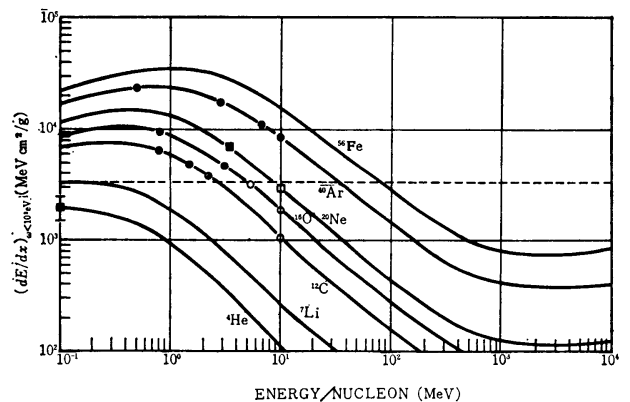

(b)

図 2 固体飛跡検出器における重イオンの nucleon あたりのエネルギーに対する REL の変化と その曲線上に示された飛跡の有無

a) cellulose nitrate,

b) Lexan (polycarbonate)

ない值である。0.1MeV/nucleon 付近での $R E L$ は確 かに精度が悪く, 実測点が $(R E L)_{\mathrm{crit}}$ 以下にあるがそ のため RELが飛跡生成の criterion として好ましく ないとはいえない。何となればより精度のよい推定法 に従えば明らかに $0.1 \mathrm{MeV} /$ nucleon 付近で $R E L$ が

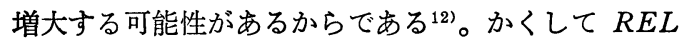
はわれわれとしても取り扱いやすいのでその実用的価 值は大きい。

\section{$1 \cdot 2$ 陽子および反跳核による飛跡の生成}

いままで固体飛跡検出器で検出し得た最も軽い荷電 粒子は陽子である*。すなわち, Jones, Neidigh は cellulose nitrate に $50 \sim 550 \mathrm{keV}$ の陽子を照射し, それを $\mathrm{NaOH}$ の溶液で etching することによりそれ ら陽子の飛跡の観測に成功した ${ }^{13)}$ 。その飛跡は非常に 短いためその観測は容易ではなく, とくに $110 \mathrm{keV}$ 以 下のところでは陽子の入射方向がかろらじて判断でき る程度であった。また確認はされていないが $2110 \mathrm{keV}$ では入射陽子と飛跡との間に $1 ： 1$ の対応があるとさ れた。しかしそののち Fleischer らの測定によれば
Nixon-Baldwin cellulose nitrate では $0.1 \mathrm{MeV} /$ nucleonの重陽子は検出されたがそれ以上のエネルギ 一の重陽子の飛跡の検出は不可能であった ${ }^{3)}$ 。た Nixon-Baldwin よりも感度のよい Daicell cellulose nitrate でも陽子の飛跡検出可能なエネルギーの上限 はせいぜい 0.3〜0. $4 \mathrm{MeV}$ で Jones, Neidighの結果 と必ずしも一致しない(14)。この程度の食い違いは cellulose nitrate の重合度の差や etching 条件の差によ って生まれる可能性もあるが, cellulose nitrateより もさらに感度の低い cellulose acetate でも陽子の飛 跡が観測された。すなわち, 最近 Varnagy, Csikai, Szegedi, Nagy は cellulose acetate に陽子を照射 し $300 \mathrm{keV}$ 以上でほぼ $100 \%$ の効率で陽子の飛跡が 生成されることを見出した ${ }^{15)}$ 。その観測結果に従えば 700 $800 \mathrm{keV}$ の陽子でも円形の etch pit を作ってい る。このような事実は前節に述べた飛跡生成の criterionからは説明できない。そのため陽子による有機 物質中での飛跡生成に関し新しい機構を考える必要が ある**。

一方 $\alpha$ 崩壊に伴う反跳核による飛跡はその生成機構 がこれまでのものとまったく異なるため，その飛跡生 成の条件を明らかにすることが必要である。すなわ ち，その反跳核のエネルギーは〜 $500 \mathrm{eV} /$ nucleonで, もしもその飛跡が検出されるとすれば電離損失により 物質に付与されたエネルギーによって飛跡が生成され るのではなく物質構成原子の核との弾性散乱によって おこる “displacement spike”によるものと考えられ る。これはいままで主として考えられてきた“ion explosion”とか “electron thermal spike”とはま ったく異なる飛跡生成の機構である。またこのような 反跳核による飛跡が天然の岩石の中に含まれる絶縁性 物質の中に見出すことができれば， ${ }^{238} \mathrm{U} の$ 自発核分裂 を利用したと同じ方法を用いてその岩石の作られた年 代の測定ができるはずである。しかもこの場合，自然 核分裂を利用する場合よりも4000倍も感度が増すもの と考えられている ${ }^{16)}$ 。そのためこの研究は主として mica のような天然に存在する物質について行なわれ ている。初め Huang, Walker は ${ }^{228} \mathrm{Th}$ を熱処理を

*ここでは decoration process による飛跡の生成 は除外した。

** 1969年フランスの Clermont-Ferrand で行なわれ た Nuclear track registration の国際会議にお いて R. Beaujean によりその 1 つの機構として multi-hit process による飛跡の生成が考えられ ている。 
すませた mica 上に蒸着, 位相差顕微鏡により反跳核 の飛跡の観測に成功した ${ }^{16)}$ 。しかし U-foil に接触さ せた mica にはその飛跡を検出することはできなかっ た。その原因としては U-foil の表面に何らかの原因 でできた薄膜のため反跳核の mica への入射が遮えぎ られたか，または ${ }^{228} \mathrm{Th}$ の場合は比較的短時間に幾つ もの $\alpha$ 崩壊を行ない同し残留核が何回も反跳を受ける ことになる一方 ${ }^{238} \mathrm{U}$ の場合にはそれがわずか 1 回に 止まることによるためかのいずれかであると考兄られ た。その後 Katcoff は ${ }^{212} \mathrm{~Pb}$ から始まり ${ }^{208} \mathrm{~Pb}$ に至 る崩壊系列や ${ }^{210} \mathrm{Po} の \alpha$ 崩壊（いずれる $\alpha$ 崩壊は 1 回 だけである）を用いて， $\alpha$ 崩壊のさいの反跳核 ${ }^{208} \mathrm{Tl}$, $\left.{ }^{208} \mathrm{~Pb},{ }^{206} \mathrm{~Pb}\right) *$ の mica による検出効率の測定を行な

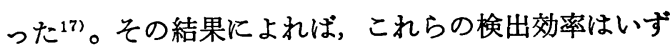
れも約 $80 \%$ で，空気によって減速されるとともにその 効率は低下するが $40 \mathrm{keV} て ゙$ 約50\%はあることが確認さ れた。しかし, Huang, Walker の場合と同様に mica 上に蒸着された濃縮ウラン $\left({ }^{235,4} \mathrm{U}\right.$ の反跳核のエネル ギーは $80 \mathrm{keV}$ である）に対しては反跳核の飛跡を見 出すことはできなかった。これは抗そらく蒸着膜が厚 すぎたか，何らかの原因で表面被膜ができたためと考 えられている。いずれにしろ一連の崩壊系列において 同し残留核が数回の反跳を受ければ 100\% の効率で飛 跡を生みだすことは確実であろう。このような反跳核 による飛跡の生成が “displacement spike” による るのであれば，従来の固体飛跡検出器の場合とは異な り，飛跡生成のためには電気伝導性が悪くなければな らないといら条件は必要なくなるはずである。そのた め極端なことをいえば金属のなかにもその飛跡を見出 しうるはずである。このように反跳核の検出は飛跡生 成の機構のらえから見ても応用面から見ても非常に興 味のある問題なので今後の発展が大いに期待される。

\section{$1 \cdot 3$ 飛跡汇影響する外部要因}

重イオンの照射中および照射前後の環境や取り扱い 等によって飛跡生成に対する感度や etching のさいの 飛跡の成長速度等が影響を受ける。ここではこれらの 諸現象のうちとくに飛跡生成機構に関係すると考えら れるものについて述べる。

飛跡の生成に影響を与える外部環境のうち，最も重 要なるのは周囲の気体の種類である。たとえば Ar の ような不活性ガスの中で重イオンを照射しても飛跡の 生成感度にはまったく变化は見られない。ところが有

*これらのエネルギーはそれぞれ117, $169,103 \mathrm{keV}$ である。
機物から成る固体検出器を $\mathrm{O}_{2}$ ガス中で重イオン照射 すると真空中で照射した場合に比べて著しく感度が增 加することが見出された ${ }^{18), 19 \% 。 た と え は ゙ ~ c e l l u l o s e ~}$ acetate に $\alpha$ 線を照射した場合などがそのよい例であ る ${ }^{18)}$ 。一般に $\mathrm{O}_{2}$ を空気に変えてもその影響に大差は ない。一方 $\mathrm{H}_{2} \mathrm{O}$ の存在も $\mathrm{O}_{2}$ の場合々同様 etching のさいの飛跡の成長速度や飛跡の検出感度に影響を与 えるが，前者のほらがその影響は大きい(19)。このよう な現象は有機物質に対する一般的な放射線効果と類似 しており, 重イオンにより飛跡に沿って作られた生成 物と $\mathrm{O}_{2}, \mathrm{H}_{2} \mathrm{O}$ または $\mathrm{H}_{2} \mathrm{O}_{2}$ との二次的反応が原因と なっていると考兄られる

つぎに照射後 etching までの間どのような環境に保 存されるかも大いに問題となる。たとえば polycarbonate を $\mathrm{Ne}$ イオンで照射し, 遮光して室温で放置 した場合, 時間とともに etching のさいの飛跡の成長 速度が速くなり, それが安定するのに1か月近くかか っている。これも上記の酸素効果に外ならない。また この保存期間に紫外線照射を行なえば, etching によ る飛跡の成長速度が著しく増加する ${ }^{201,21)}$ とともに飛 跡の最大長さも増加する ${ }^{21)}$ 。しかしこのような現象は 周囲に空気または酸素が存在しているときにのみ起こ

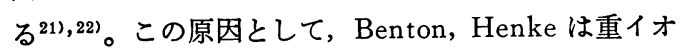
ンの通路に沿って作られた放射線損傷の部分は他の部 分よりも紫外線をよく吸収するため, 重イオン照射後 に打ける紫外線の照射は飛跡に沿った吸収エネルギー の增加をきたし, その結果固体検出器の感度拈よび etching による飛跡の成長速度の增大をもたらすと考 え, 逆にこのような現象を飛跡検出器の性能の向上の ために利用することを提案している ${ }^{22)}$ 。しかしこのよ らな理由だけでは酸素の必要性については理解できな い。技そらく重イオンにより生成された細かい分子片 が酸素ガス中で紫外線を受けることにより酸化し， etching 溶液に溶解しやすくなると考光るべきであろ $\zeta^{21)}$ 。また $\mathrm{N}_{2}, \mathrm{~N}_{2} \mathrm{O}$, NO 等の窒素化合物中での紫外 線照射はむしろ etching による飛跡の成長速度の低下 をむたらす ${ }^{21,23)}$ 。これらの紫外線照射によって起こる 諸現象を完全に理解することは困難であるが，有機物 質に対してこのような現象が起こる以上, 重イオンの 飛跡に沿って生じる小分子片の役割を重視すべきで, これらの生成には必ずしも“ion explosion”の必要は なく，むしろ飛跡生成の機構を考劣るにあたっては飛 跡に沿った吸収エネルギーの分布(これは小分子片の 密度分布に比例するはずである）を問題とすべきであ ろう。 

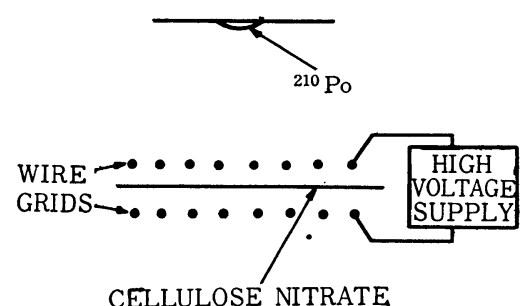

図 3 Cellulose nitrate における飛跡生成のた めのエネルギーのしきい值の電場効果測定 用装置の概略

以上のような紫外線照射効果とは別に興味ある外的 条件の 1 つして飛跡生成に対する電場効果があげら れる。すなわち, Crannell, Crannell, Kline は図 3 に示すような 2 つの゙リッド状電極の間に cellulose nitrate を挿入し上部より ${ }^{210} \mathrm{Po} の \alpha$ 線を照射してそ の飛跡生成のためのエネルギーのしきい値の電場効果 を調べた ${ }^{24)}$ 。その結果, 電場の存在しないときは, $3.5 \mathrm{MeV}$ 以上の $\alpha$ 粒子は etchable な飛跡を生成でき なかったが， $6 \times 10^{4} \mathrm{volt} / \mathrm{cm}$ 以上の電場が存在すると きには etchable な飛跡が生成された。また $1 \times 10^{5}$ volt $/ \mathrm{cm}$ の電場での飛跡の検出効率は $4 \mathrm{MeV}$ の $\alpha$ 粒 子に対して $80 \pm 20 \%$ と推定された。この程度の電場で は cellulose nitrate の内部でイオンの増殖を行なう ことは不可能であり, 以上のような検出器の感度の増 加は“ion explosion”説では説明は困難である。その 後, Crannell らは新しい装置を用いて電場効果の研 究を進め, $\alpha$ 線照射直前に電場を切っても同程度の飛 跡検出効率の増加を見出した ${ }^{25)}$ 。その結果, かれらは かかる電場効果は電場の直接的影響によるものではな く, 検出器表面付近での放電によるオゾンの増加に起 因するるのと解釈しているようである。

$1 \cdot 4$ 新しい飛跡検出器 (glass chamber)

最近 2 種の液相ガラスの混合系における混和と分離 に対する準安定状態を利用した新しい型の飛跡検出器 か Srinivasan, Younger, Macedo, Litoritz によっ て開発された ${ }^{26)}$ 。すなわち，かれらは完全に混和して いる 2 種のガラスの混合系で，わずかな騒乱でいずれ かのガラスが析出するような準安定状態が存在するこ とに着眼し, 室温でそのような状況を作りうる混合系 として $\mathrm{Na}_{2} \mathrm{O}-\mathrm{SiO}_{2}$ (重量比 2:8) を使用した。すな わち，まずこの混和状態にある系を結晶を作ることな く混和点以下に過冷却し, この混合系に和ける準安定 状態 (室温でガラス) に拈く。その混和点では混合系 の粘性が高いため, 混和状態から液相分離の状態への
遷移は緩慢で容易にかかる準安定状態を作り出すこと ができる。いまこのようなガラスに重イオンを照射す れば，当然その飛跡に沿って放射線損傷が生じ，そこ にェネルギーがたくわえられる。ついでこのガラスを 加熱し混和点の下数度のところ（この実験では 593.5 $\left.{ }^{\circ} \mathrm{C}\right)$ で約 1 時間熱処理を行ならと飛跡に沿ってたくわ えられたエネルギーによって $\mathrm{SiO}_{2}$ の相が析出するこ とになる。Srinivasanらは実際このような混合系を使 用して, ${ }^{235} U$ の核分裂片の飛跡の観測に成功した。こ の方法がさらにに進めば，混和状態にあるガラスと析 出ガラスとの屈折率の差を利用して, 簡単な熱処理を 行ならのみで表面のみならず固体内の飛跡まで観測で きるようになろう。Srinivasan らは以上のような原 理に基づく飛跡検出器を泡箱との類比においでglass chamber”と呼んでおり, 今後の発展が期待される。

\section{2. 飛跡観測技術}

固体飛跡検出器が実用化されてからすでに10年を経 たが，その応用分野の広がりとともに飛跡の測定精度 に対する要求もしだいに厳しいものになりつつある。 また表面に出た飛跡のみでなく固体内の飛跡をも観測 したいという要求も強い。一方測定の統計的精度を上 げるため大面積の飛跡検出器が使用され始めたためそ の scanning の技術もいろいろと開発されつつある。 ここでは以上の諸点を中心に最近の飛跡観測技術の発 展について述べる。

\section{$2 \cdot 1$ Chemical etching}

固体飛跡検出器に拈いて測定さるべき量としては， 飛跡の長さ $L$, etching による飛跡の成長速度 $v_{T}$, etching によって生まれる円錐状飛跡の頂角 $\theta$, 飛跡 の太さ $D$ 等があるが, 重イオンの飛程に近い飛跡の長 さの測定を除いて，これらはいずれも etching の条件 によって左右される量である。したがって etching の 条件をいかに一定に保つかによってこれらの測定精度 がきまるといっても過言ではない。のちに述べる荷電 粒子の弁別にはこれらの量の測定を伴うゆえ，その性 能を向上させるためには etching の条件を明確にして おく必要がある。

先にも述べたごとく酸素効果は無視することはでき ないので polycarbonate のようなものに対しては重 イオン照射後遮光の状態で 1 月ほど保存しておく必要 がある ${ }^{20)}$ 。また当然 etchant の純度が高いこと，その 濃度および温度がむらなく一定であることが要求され る。最近 Peterson は polycarbonate の膜を $\mathrm{NaOH}$ 


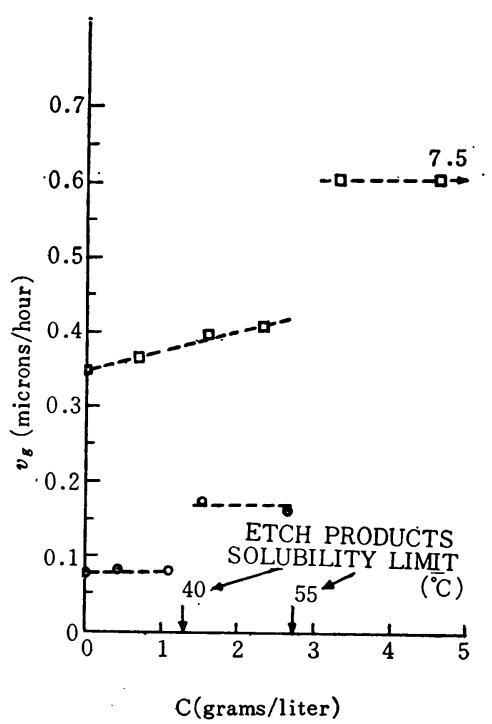

(A)
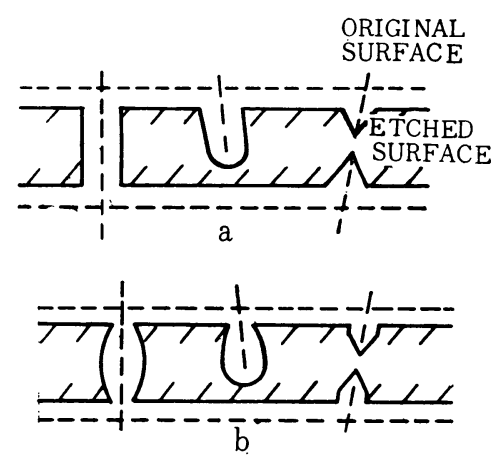

(B)

図 4 (A) $\mathrm{NaOH}(6.25 \mathrm{~N})+0.05 \%$ Dowfax $2 \mathrm{~A} 1$, $55^{\circ} \mathrm{C} て$ Lexan (polycarbonate)を etching した場合の etch product に対する $v_{G}$ の 変化

(B) a : saturated etchant での飛跡の形状 b: unsaturated etchant での飛跡の 形状

の溶液で etching した場合, 放射線損傷を受けてい ない膜の表面での etching 速度 $v_{G}$ が etching に よる生成物の濃度の增加ととるにふえることを見出し た ${ }^{27) 。 さ ら に ， か か る ~} v_{G}$ の増加は etching による生 成物の溶解が限度に達したときに飽和すること，また このように飽和した etchantを使用した場合, より なめらかな綎断面をるった飛跡が得らることがわかっ た。これらの模様を図 $4(\mathrm{~A})$, (B)に示す。なにゆえ $v_{G}$ が このような变化を示すかはいまのところくわしくはわ かっていないが，前に列挙せる諸量の測定にとって重
視すべき事実である。

また etchant として $\mathrm{NaOH}$ や $\mathrm{HF}$ の溶液がそ れぞれ単独に使用される場合が多いが固体飛跡検出器 によって最適な etchant としてかなり複雑な組成の るのを使用する場合もある。たとえば Somogyi らに よれば cellulose acetate に対しては $25 \mathrm{~g} \mathrm{NaOH}$ $+20 \mathrm{~g} \mathrm{KOH}+4.5 \mathrm{~g} \mathrm{KMnO}_{4}+90 \mathrm{~g} \mathrm{H}_{2} \mathrm{O}$ の溶液を $50^{\circ} \mathrm{C}$ で使用するのがよく，それによっでミ240 keV の重 陽子を検出できるが，同じ etchantを使用した場合 一般に cellulose acetate より感度がよいとされてい る cellulose nitrate では $0.8 \mathrm{MeV}$ の三重陽子さ える検出できなかった ${ }^{28)}$ 。先に述べた cellulose acetate による陽子の検出もこの種の etchant を使用し た結果である。このように使用せる etchant によって 飛跡生成の感度が著しく変わるものであれば，たとえ 同じ飛跡検出器を使用しても etchantによってそれぞ れ異なった飛跡生成のためのしきい值を設定しなけれ ばならなくなるであろら。

\section{$2 \cdot 2$ 固体内飛跡の観測}

一般に chemical etching 法ではいわゆる潜在飛 跡が表面ないしはそのごく近傍に達している場合にの み飛跡を払大できるに過ぎない。一方鉱石や隕石等自
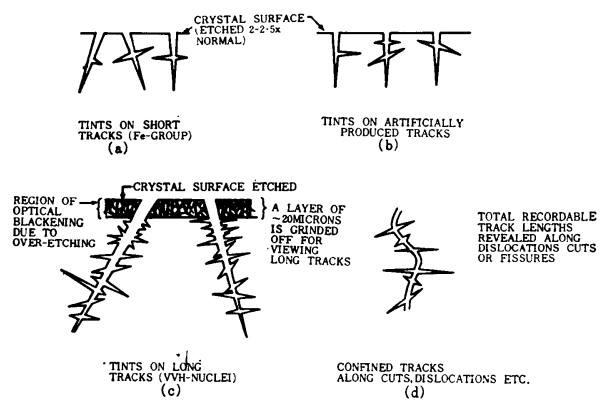

(A)

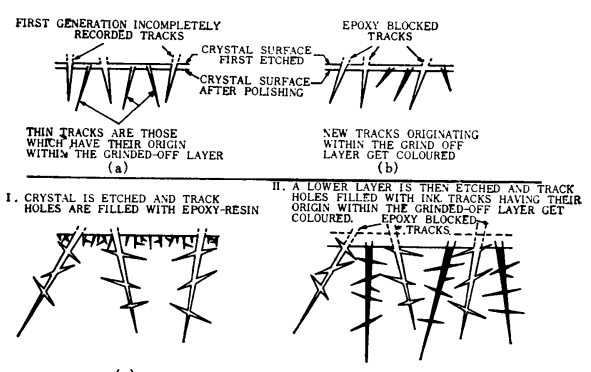

(c)

(B)

(d)

図 5 固体内飛跡の長さ測定法の説明図 (A) TINT 法, (B) TOT 法 
然に存在する物質の内部に存在する飛跡の長さの分布

（これは後述するように核電荷分布を表わす）の測定 や核反応により生成された 2 個以上の核による立体的 飛跡の観測等固体内で発生した飛跡を直接観測したい という希望もかなり強い。

Lal は隕石内部で発生した飛跡の長さの分布を測定

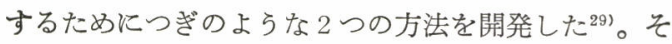
の 1 つは比較的短い長さの飛跡の測定のためのもので 図 5 (A)に示すごとく隕石の表面から内部に向かって延 びている比較的長い飛跡(collimateされた核分裂片等 による人工飛跡をも含む) や䢃開面に沿ってそれと交 叉している飛跡が etching の進行とともにしだいに現 われ隕石内に打けるそれらの飛程分布が容易に測定で きるよらになる。また測定せんとする飛跡の長さが長 い場合には図 5 (B)に示すようにまず表面を etching し それによって生まれた飛跡をエポキシ樹脂で埋めふた たび etching を行なら。そのさい生成された飛跡は2 回目の etchingにより除去された表面層から発生した もので，その長さを測定すれば隕石内に打ける飛跡の 長さを知ることができる。Lal は初めの方法をTINT (track in track) 法*, あとの方法をTOT 法と名つ け隕石や月の試料の内部に記録された飛跡の飛程分布 を求めている29, 30)。

一方核反広の研究に打いても上記のTINT法と同様 な試みが Benton によってなされだ1)。すなわち, 図6 (A) に示すように固体飛跡検出器の表面に直角に適 当なエネルギーをもつ重イオン（たと㓪ば40 Ar）を照 射し, 表面密度の高い潜在飛跡をかなりの深さにわた って作って扣く。できればかくして作られた飛跡がち ようど突き抜ける程度の厚さの検出器を使用すること が望ましい。これをetchantに浸せば両面からetching が進行して貫通した多数の etch channelが現われる。 もしもこの etch channel に他の荷電粒子の飛跡が交 叉すればそれも同時に etching されるはずである。そ こでこの etch channel に直角に興味ある粒子を入射 させて内部で起こる反応を立体的に観測することが可 能である。図 6 (B)は $10 \mathrm{MeV} /$ nucleon の ${ }^{40} \mathrm{Ar}$ を照射 して多数の etch channel が作られている cellulose nitrate の深さ $40 \mu$ 程度のところの ${ }^{12} \mathrm{C}$ の飛跡を示 す。

\section{$2 \cdot 3$ 飛跡の scanning}

固体飛跡検出器には測定すべき飛跡の密度がきわめ て高い場合と極端に低い場合とがあり，いずれの場合 も手間を省くために計数の自動化や飛跡の簡単な検出

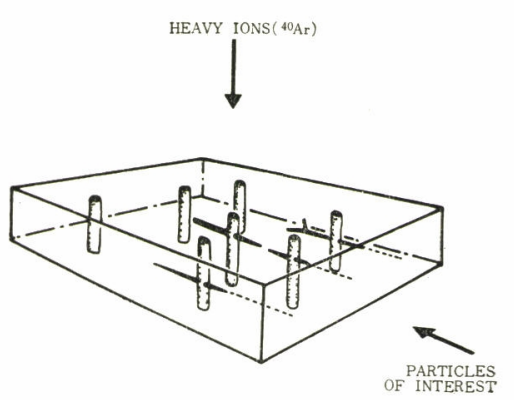

(A)

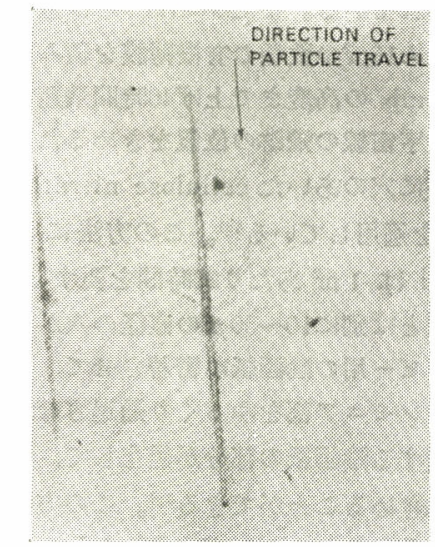

(B)

図 6 重イオン照射による固体内飛跡の観測 (A)説明図，(B)この方法を用いて観測された cellulose nitrate 表面下 $40 \mu$ のころの ${ }^{12} \mathrm{C}$ の飛跡

方法がいろいろくふらされている。

たと壳ば $10^{4} \sim 10^{6}$ 個 $/ \mathrm{cm}^{2}$ の密度領域に持ける飛跡密 度の測定のため, 飛跡による散乱光を光電子増倍管で とらそその出力を直流増幅器で増幅して, 飛跡密度を 電流として示す方法が試みられている ${ }^{321}$ 。その場合, 最大の signal to background ratio を示す最適の散 乱角（検出器の物質によって異なる）が存在すること がわかった。実際のテストはガラスおよび polycarbonate の核分裂片の飛跡について行なわれ満足すぺ き結果を得ている。1 $70^{7} \sim 10^{8}$ 個 $/ \mathrm{cm}^{2}$ の飛跡密度は光学 顕微鏡に和ける測定の限界であり，これ以上の密度を もつ場合には etching をわずかにし走査型の電子顕 微鏡で計数しなければならない33)。また television image analyzer を利用して自動的に個々の飛跡を計 数する装置も作られ実用化されている ${ }^{34)} 。$

一方飛跡の密度が低く，かつ飛跡が検出器を突き抜

*人工的に作られた䢃閉面を利用する場合を TIN

CLE 法 (a track in the cleavage) と呼ぶ。 
ける場合, 検出器に強い電場を加光, その穴に沿って 起こる気中放電により飛跡の位置をきめることがしば しば行なわれている。たとえば Lark は走查型光学顕 微鏡を改造し，対物レンズの部分に針またはカミソリ の刃を固定し, それと飛跡検出器（厚さ $8 \mu$ の polycarbonate)を乗せた走査台との間に電圧をかけること により核分裂片の飛跡の位置の決定を試みている ${ }^{35) 。}$ これと同じ放電方式を用いて飛跡密度の高い場合にも 使用できる自動計数装置 (位置の決定も可能) の開発 が Cross ${ }^{36)}$ や Becker, Boyett, Johnson $5^{37)}$ によ って行なわれている。またWalkerらは重一次宇宙線 の検出のため $15 \mathrm{~m}^{2}$ の数種の有機薄膜を積み重ねたもの を気球で $4 \mathrm{mb}$ の高度まで上げ40時間飛翔させ, 得ら れた重一次宇宙線の飛跡の位置をきめるため etching により容易に穴のあいた cellulose nitrate $に$ spark scanningを適用している ${ }^{38)}$ 。この方法による scanning speedは $1 \mathrm{~m}^{2}$ あたり20時間を要する。

この方法とは別に10〜 50 $\mu$ の直径の穴があいた有機 薄膜をリコピー用の陰画紙に密着させて, リコピー用 の機械のアンモニア部をゆっくり通過させれば，穴の 位置に相当する陰画紙の部分が黒化して, 飛跡の位置 をただちにきめることができる391。この方法によれば $1 \mathrm{~m}^{2}$ たり数分しかかからずにすむといわれている*。 Fleischer らは重一次宇宙線の飛跡の scanning 法と してはもっぱらこの方法を使用している40)。

\section{3. 荷電粒子の核種弁別}

最近では固体飛跡検出器は重荷電粒子の検出のみな らずその核種の弁別のためにも広く利用されるように なった。初めは検出器の種類によってREL や $d J / d x$ のしきい值が異なるのを利用して大まかな核種の弁別 を行なう程度に過ぎなかったが，しだいにその方法る 精密の度を加え, 場合によっては原子核乾板を使用す る場合よりもよい精度が得られるようになった。固体 飛跡検出器飞抢いて, 測定しらる有意な量としては, 1) 残留飛程 $R, 2 ）$ 検出器内での記録されらる最大飛 程 $\left.R_{\mathrm{reg}}, 3\right)$ etchingによる可視的飛跡の成長速度 $v_{T}$, 4) etchingによって飛跡に沿って作られた円錐の頂角 $\theta ， 5 ）$ 円錐の太さ（たとえば円錐の軸に直角な円断 面の直径) $D$ 等である。ここで $\theta$ は次式によってきま る量であり，

$$
\theta=\sin ^{-1}\left(v_{G} / v_{T}\right)
$$

$D$ む $v_{G}$ と $v_{T}$ との関数であるため, 飛跡についてはい

*Ozarid copy machine を使用した場合の值であ る。 ずれるv゙に関する情報しかもっていない。ただ $v_{a}$ と大差ない場合には $R$ や $v_{T}$ の直接の測定は困難と なるため，かわりに $\theta, D$ の測定が行なわれるにすぎ ない。したがって荷電粒子を并別する方法としては $R, R_{\mathrm{reg}}, v_{T}$ の 3 つの組合わせを考光ればよい。そのた

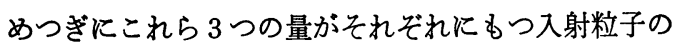
情報について示す。

$$
\begin{array}{ll}
R: & \beta, Z, M \\
R_{\mathrm{reg}}: & Z, M \\
v_{T}: & R E L(Z, \beta) \text { または } d J / d x(Z, \beta)
\end{array}
$$

現在までに行なわれている粒子弁別の方法としてはつ ぎのような組み合わせがある。

i ) $R_{\text {reg }}$ による $Z, M$ の弁別

ii ） $R$ に対する $v_{T}$ の変化を測定することによる $Z$, $M$ の弁別

iii） $v_{T}$ のみの測定による $Z$ の弁別（ただし $\beta \sim 1$ の 粒子に対してのみ適用される)

ここではこれらの具体的方法やそれらの現時点におけ る到達精度等について述べてみたい。

\section{$3 \cdot 1$ 飛跡の直径Dによる粒子の弁別}

固体飛跡検出器に垂直入射する荷電粒子の飛跡の直 径Dは当然 etching の時間とともに增大する。その変 化曲線は $v_{T}(Z, \beta)=v_{T}(Z, R)$ の関数であるゆ元, 荷 電粒子の種類によってそれぞれ異なる。しかし，いま までのところこのような方法で粒子の弁別を試みた例 は少ない。初め Somogyi は cellulose nitrate に拉 ける $\alpha$ 粒子の飛跡やガラスでの核分裂片の飛跡でかか るDの etching による時間变化( $D-t$ 曲線)の測定を行 なったが，その狙いはむしろ粒子のエネルギー決定に あった ${ }^{41}$ 。その後同様な方法で $\mathrm{D}+\mathrm{D}$ 反応や $\mathrm{D}+\mathrm{T}$ 反 応によって生まれた $,{ }^{3} \mathrm{He},{ }^{4} \mathrm{He} の D-t$ 曲線の測定を 行なっているが，明らかにこれらの粒子の弁別に成功 している ${ }^{28)}$ 。一方 Höpper, Konecny, Fiedler はAu の薄膜を通して減速された核分裂片を用いて核分裂片 のエネルギーとそれによって作られた飛跡の直径との 関係を種々の etching 時間について求め, etching 時 間を十分長くして測定したときの ${ }^{252} \mathrm{Cf}$ の自発核分裂 片の etch pit の直径の分布が半導体検出器により得 られたそのエネルギー分布と比較的よく一致している ことを見出した ${ }^{42)}$ 。Fleischer, Price, Woods は各種 のガラスの核分裂片汶対する入射臨界角 $\varphi_{c}(=\theta)$ を測 定し，それからそれぞれのガラスについての primary ionization と $v_{T} / v_{G}$ との関係を求めた年。またその 関係を仮定して計算から求めた etch pit の直径の時 


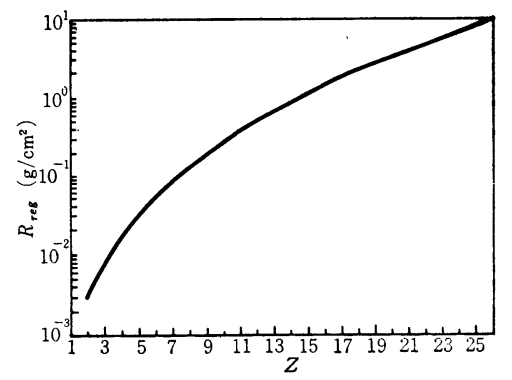

図 7 Cellulose nitrate における $Z$ に対する $R_{\mathrm{reg}}$ の変化, 同位元素の存在する場合には 存在比の最も大きなものに対して計算され た。

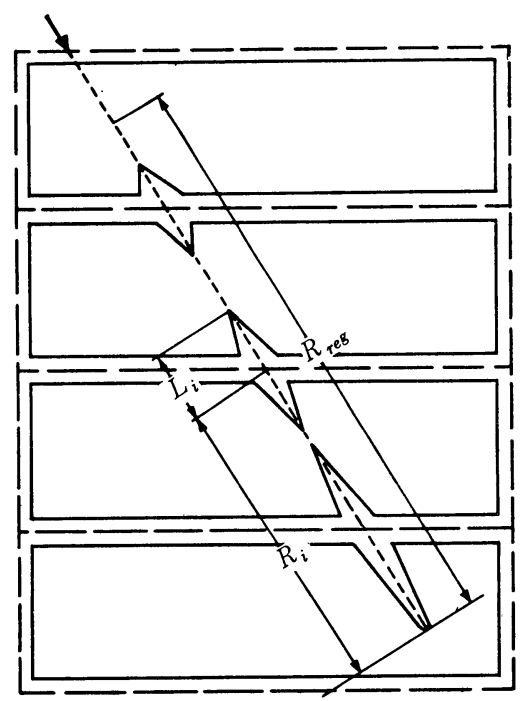

困 8 Organic film stack 法による $R_{\text {reg }}, R, L$ の測定

間変化は Höpper らの実測結果ときわめてよい一致を 示した。この事実はこの方法もかなりの程度定量化し らるといらことを示している。

\section{$3 \cdot 2 R_{\text {reg }}$ による粒子の弁別}

外部から入射せる荷電粒子は初めそのエネルギーが 高いらちはその $R E L$ は (REL) erit 以下にあるため 潜在飛跡を作らないが，物質通過の間にしだいにその エネルギーを失い $R E L>(R E L)_{\mathrm{crit}}$ の条件を満たす ようになって初めて潜在飛跡が生成されるようにな る。さらにその粒子のエネルギー損失が進み, 停止直 前のところでふたたび $R E L<(R E L)_{\mathrm{crit}}$ となりそこ で潜在飛跡の生成は終る。固体飛跡検出器内部でこの ようにして生成され, かつ終る潜在飛跡の全長 $R_{\mathrm{reg}}$ は $Z$ とMのみの関数であり, $(R E L)_{\mathrm{crit}}$ が正確に与えら
れれば計算から容易に求めることができる量である。 したがって $R_{\mathrm{reg}}$ が精度よく測定できれば，それと計 算から得られた飛程とを比較することにより，核電荷 はもとよりその質量数まで決定できることになる。図 7 は Benton, Henke によって計算された cellulose nitrate での $R_{\text {reg }}$ 対 $Z$ の関係を示す44)。この計算で は $M$ としては同位元素のうち最も豊富に存在するもの の値を使用している。実際上は何枚かの固体飛跡検出: 器を積み重ねてその上から重イオンを照射し, これら を etching することにより検出器内部に発生した飛 跡を観測する。そのさい四 8 のように明らかに内部で 発生しかつ停止している飛跡が見出されればそれから $R_{\text {reg }}$ を測定することがでさる。Benton らは 1 in. X3 in.の面積をもち $500 \mu \mathrm{m}$ 厚の cellulose nitrate 12枚 を積み重ねたものを気球に塔載しカナダ・Manitoba 上空 $144,000 \mathrm{ft}$ を約 11 時間にわたって飛翔させ $R_{\mathrm{reg}}$ 法による重一次宇宙線の核電荷分布の測定を試みた。 そのさい得られた核電荷弁別の精度は $Z=18$ に対し, $\Delta Z= \pm 0.3, Z=7$ に対し $\Delta Z= \pm 3$ であった。この 実験での $R_{\mathrm{reg}}$ の測定精度では同位元素の弁別は困難 であるがくららしだいによってまだ粒子の弁別精度を 上げることは可能であろら。この方法は Fleischer ら によって隕石中の重一次宇宙線による飛跡の解析にも 使用されているが45),46)，(REL) crit にある程度の幅: があることと $R_{\mathrm{reg}}$ の理論的推定值にかなりの曖昧さ があるため思ったより核種決定の精度が悪いというの が現状である。

\section{3・3 R と $v_{T}$ とによる粒子の弁別}

etching による飛跡生成の速度 $v_{T}$ は潜在飛跡生成 のための criterion REL（または $d J / d x$ ) のみの関 数と考劣られる。たがって残留飛程 $R$ に対する $v_{T}$ の変化の割合は

$$
\left(\frac{d v_{T}}{d R}\right)_{R E L}=\left(\frac{d v_{T}}{d(R E L)}\right)_{R E L} \cdot\left(\frac{d(R E L)}{d R}\right)_{R E L}
$$

と書き表わすことができる。ここで( $\left.\frac{d v_{T}}{d(R E L)}\right)$ は検出 器の材料, etching の条件によってきまるもので入射 粒子の種類に無関係である。また $\frac{d(R E L)}{d R}$ は与えられ た $R E L$ に対して $Z$ と $M$ のの関数である。いま残留 飛程 $R$ に対する $v_{T}$ の変化の曲線を求めれば, 同じ $v_{T}$ すなわち同じ $R E L$ での $\left(\frac{d v_{T}}{d R}\right)_{R E L}$ は $Z$ とMのみの関 数として与えられる。したがって $v_{T}-R$ の関係は入 射粒子の核種によってそれぞれ異なった曲線を示すは ずである。このような原理に基づいた粒子の弁別は 


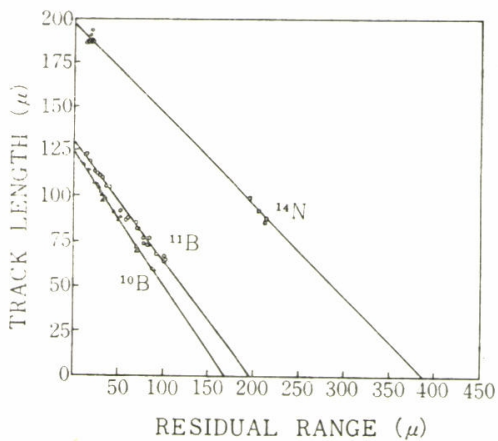

図 9 Cellulose nitrate stack 法による ${ }^{14} \mathrm{~N}$, ${ }^{11} \mathrm{~B},{ }^{10} \mathrm{~B}$ の $L\left(\bar{v}_{T}\right)$ 対 $R$ の関係

Price, Fleischer, Peterson らによって提案され, 加速器から得られた重イオンの核種弁別に利用され た ${ }^{47)} 。 v_{T}-R$ の測定のため Price らの用いた方法はま ず図 8 のような有機薄膜の積み重㸚を使用し，これら を同一条件で時間 $t$ だけ etching して，飛跡に沿って それぞれの薄膜に作られた円錐形の etch pit の長さ $L_{t}$ を求め, ついで飛跡の最終端を含む薄膜に十分な etching を㴗どこしその飛跡の最終端の位置を確認す る。ここで $L_{i}$ は残留飛程 $R_{i}$ の点に䍩忷る時間 $t$ 内の 平均の $v_{T}$ を表わしていると考光てよい。したがって 求める $v_{T}$ と $R$ の関係は図 9 亿示すような $L$ との関 係として表わすことができる。図からわかるように ${ }^{10} \mathrm{~B}$ と ${ }^{11} \mathrm{~B}$ が明らかに弁別されている。さらに精度を 向上させることにより質量数10以上での同位元素弁別 も可能になるかも知孔ない。この方法は重一次宇宙線 のうち比較的低エネルギー領域 ( $200 \mathrm{MeV} /$ nucleon) での核電荷分布の測定に利用されている ${ }^{48)}$

また原理はまったくこの方法と同じであるが, etching 後に得られる円錐状飛跡の形状からそ飛跡に招 ける $v_{T}-R$ の関係を求めることができる。すなわち, 図10(A) 亿典型的な etch pit の断面形状を示す。いま 残留飛跡 $R$ に打ける飛跡方向の etching 速度を $v_{T}$ $(R)$ ，飛跡内面に垂直な方向の etching 速度を $v_{G}$ と すれば，Rから飛跡内面に下された垂線によってきま る点 $(x)$ での切平面の軸位対する角度 $\theta$ は(5)式によっ てきまる。また飛跡断面の直径を $D$ とすれば， $R$ と $\theta$ はそれぞれ次式で与えられる。

$$
\begin{aligned}
& R=x+1 / 2 D(x) \tan \theta \\
& \tan \theta=1 / 2 d D / d x
\end{aligned}
$$

これらから $x$ 点に和ける $D$ と $\theta$ または $D$ と $d D / d x$ が 測定できれば $v_{T}(R)$ を求めることができるわけであ る。Fleischer らは Apollo 8 号の宇宙飛行士の poly. carbonate でできたへルメットを $\mathrm{NaOH}$ の溶液で

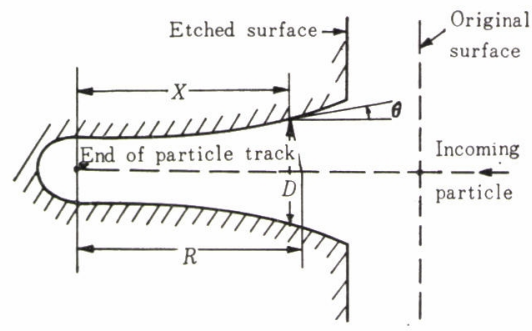

(A)

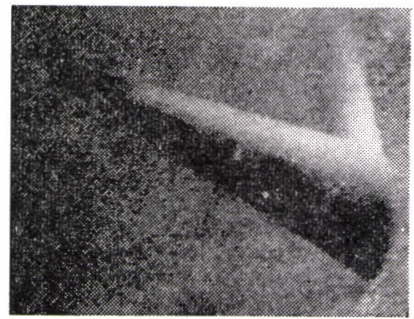

(B)

図10 (A) 垂直入射せる重イオンにより作られた etch pit の断面の形状

(B) Apollo 8 号の宇宙飛行士のへルメッ トで見出された Ni イオンによる etch pit $の$ silicon rubber replica

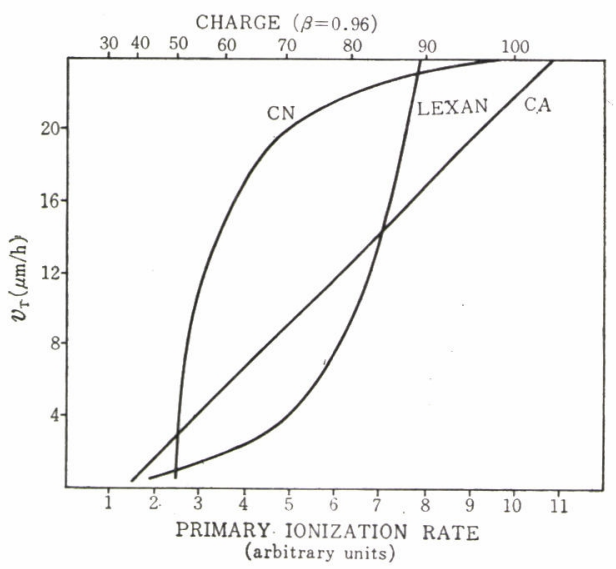

図11 Cellulose nitrate, cellulose acetate, polycarbonate (Lexan) での $v_{T}-(d J /$ $d x$ ) 曲線

etching し，シリコン・ゴムで宇宙飛行中にできた飛 跡のレプリカをとり，その形状からその核種の判定を 行なっている49)。図10 (B)はかくして得られた Ni イオ ンと推定される飛跡のレプリカである。

\section{$3 \cdot 4 \quad v_{T}$ による核種の弁別}

もしも $\beta$ が別の方法から求められれば， $v_{T}$ のみの 測定で核種の決定が可能である。この方法は Price, 
Fleischer らによって主として相対論的速度領域にあ る重荷電粒子の核電荷の弁別に使用されている の場合まず加速器等によって得られる重イオンを利用 して $v_{T}$ と $R E L$ または $d J / d x$ との関係をあらかじ め求めて打き，何らかの方法で $\beta$ を推定することがで きれば $R E L$ または $d J / d x$ に対応して $Z$ の推定がで きるわけである。眓11はかくして得られた cellulose nitrate, cellulose acetate, polycarbonate (Lexan) それぞれの $v_{T}-d J / d x$ (または $Z$ ) 曲線である。最 近 O'Sullivan, Kobetich, Shirk, Price は120枚の polycarbonate の薄膜を積み重ねたものを気球で高空 に上げ数十時間飛翔させて重一次宇宙線の観測を行な ったが，たまたまこれらを完全に突き拔け，しかも場 所によって $v_{T}$ が注とんど変わらぬものを見出した。 そこでこの粒子に対して $8 \mathrm{GeV} /$ nucleon のエネルギ 一を仮定し図11のような校正曲線に基づいて核電荷を 推定したところ $Z=78 \pm 0.6$ なる結果を得た ${ }^{51)}$ 。四12は

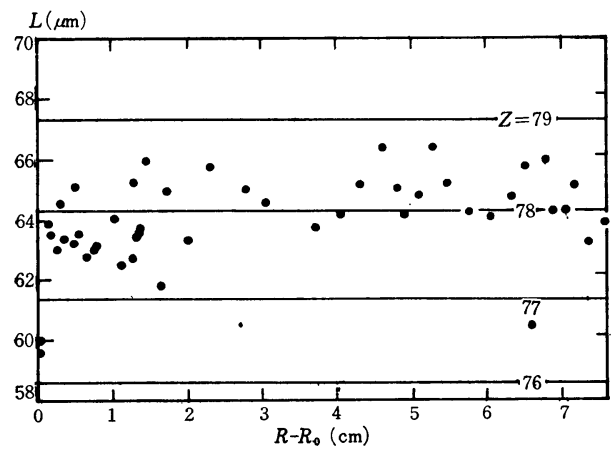

図12 120枚の Lexan sheet の stack nucleonの重イオンが貫通したときの各 Lexan sheet における $L$ の測定結果 : $R_{0}$ は Lexan sheet 通過後のLexan中の飛程

この場合の各 polycarbonate層に打ける $L$ の測定値の バラッキを示す。これに対し原子核畭板により同じ粒 子について得られた推定核電荷は $Z \approx 76 \pm 3$ で, はる か飞固体飛跡検出器のほうが相対的推定精度が高いこ とを示している。

\section{$3 \cdot 5$ 核分裂片の質量分布の測定}

核分裂のさいに放出される 2 つ核分裂片のそれぞ れのエネルギーを同時に測定することによりその質量 分布が得られることは周知の事実である。この原理を 固体飛跡検出器に適用するためには核分裂片に対する 飛程と質量およびェネルギーの関係を知る必要があ る。Ait-Salem, Gerhardt, Gönnenwein, Hipp, Paap はつぎのような経験公式を使用して $15.3 \mathrm{MeV}$

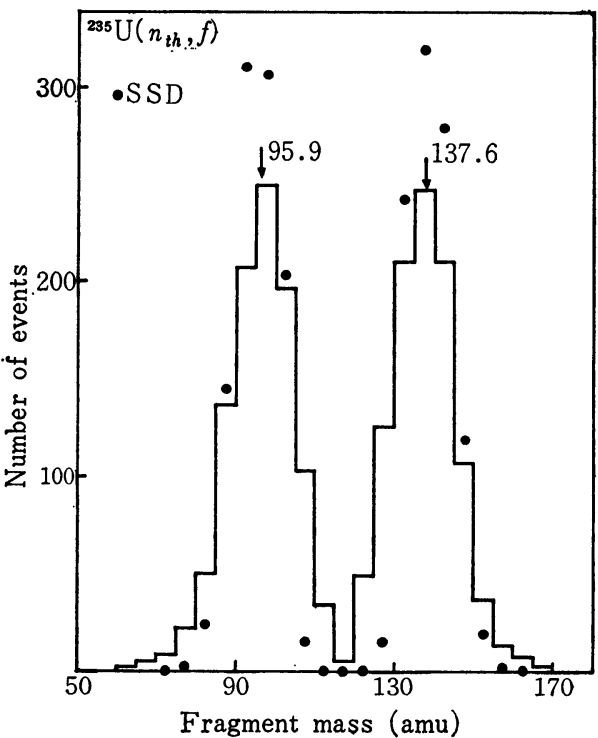

図13固体飛跡検出器によって求められた ${ }^{235} \mathrm{U}$ $\left(n_{\text {th }} \cdot f\right)$ の核分裂片の質量分布, ○は半導 体による測定結果を示す。

および4. $65 \mathrm{MeV}$ の中性子によって誘起される核分裂 に淤ける質量分布の測定を試みた ${ }^{52)}$ 。

$$
R=c\left\{0.129+\left(A-A_{0}\right)^{2} / 87900\right\} E^{2 / 3}
$$

ここで $A$ と $E$ は核分裂片の質量数とエネルギーを, $A_{0}$ は $\frac{\bar{A}_{L}+\bar{A}_{H}}{Z}$ を，cは検出器の材料にのみ依存した定数 をあらわす。その結果半導体検出器によって得られた 質量分布よりは悪いが，一応それらしいものは得られ ている。筆者らも $R=K A^{-1 / 6} E^{-1 / 2}$ なる関係を用い て， ${ }^{235} \mathrm{U}$ の熱中性子による核分裂での質量分布を求め た ${ }^{12)}$ 。その結果を図13に示す。筆者らは現在かかる核 分裂片の核種弁別法を利用して $R E L$ の大きな領域に 打ける $v_{T}-R E L$ 曲線を求めることを試みつつある ${ }^{53)}$ 。

\section{4. 固体飛跡検出器の応用}

固体飛跡検出器の応用範囲はあまりにも広く，その 現状をくまなく説明することは困難なので，ここでは 原子核，宇宙線执よび宇宙物理，原子力等の方面に重 点をおいて筆者の興味ある応用例を紹介するに止めた W。

\section{$4 \cdot 1$ 原子核関係}

原子核関係で最も多く使用されているのは核分裂の 実験に関してであろう。検出器としては軽い粒子に対 する感度の悪いガラス, mica, polycarbonate 等が用 いられている。とくにしきい值付近での断面積や角度 


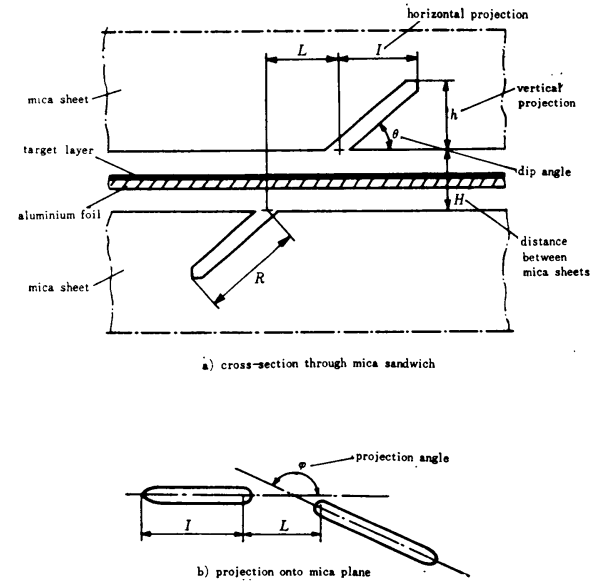

図14核分裂の研究に使用される sandwich 法の 解説図

分布の測定, 高エネルギーのbinary, ternary fission, spallation 等の断面積の測定，自発核分裂の寿命の測 定等に使用される場合が多い。また $\mathrm{GeV}$ 以上のエネ ルギー領域での利用は少ないが，バックグラウンドが きわめて低いといら点からみて将来大いに利用される ようになるものと思われる。このような高エネルギー 核反応の研究は現在 BNL のグループ54) と CERN を 中心としたグループ55) 59) とで行なわれており,図14に 示すようなターゲットを飛跡検出器ではさんだ sand. wich 方式が使用される場合が多い。いままでのとこ ろ単なる断面積や角度分布の測定が55),56),58), せいぜ い多くの仮定に基 いて kinematics から粗い質量分 布の推定 ${ }^{57)}$ を行なっているにすぎないが，将来は前節 に述べた方法等を用いて質量分布の直接の測定も可能 になるものと期待される。また高エネルギー加速器周 辺での変わった使い方の例として $600 \mathrm{MeV}$ 陽子の全 ビーム強度やその断面での強度分布の測定をあげるこ とができよう60)。これは cellulose nitrate の薄膜に 垂直に $10^{11} \sim 2 \times 10^{12}$ protons $/ \mathrm{cm}^{2}$ のビームをあて光学 密度計でビーム強度の分布を測定するもので, 生成さ れる飛跡は明らかに陽子自身のものではなく弾性散乱 とか核反応によって生まれる二次的重荷電粒子による ものと考えられる。

自発核分裂の寿命の測定に固体飛跡検出器がよく使 用されるが，つぎに述べるものは比較的短寿命のもの について用いられた珍しい例である。すなわち，Dubna の Flerov, Oganesian, Lobanov らのグルー プ61)は ${ }^{243} \mathrm{Am}+{ }^{22} \mathrm{Ne}\left(E_{\max }=175 \mathrm{MeV}\right)$ の反応に打い て ${ }^{261} 105$ が生成されていることをその $\alpha$ 崩壊の模様か

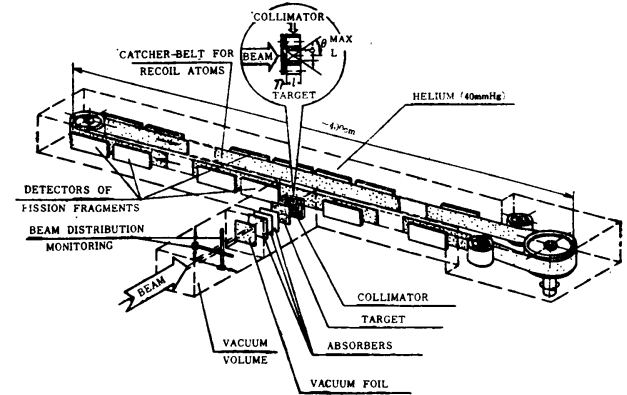

図15 ${ }^{261} 105$ 元素の自発核分裂による寿命の測定 に使用された装置

ら推論はしたものの確認はできなかった。もしもこの 元素が上の反応で作られるものとすれば，その自発核 分裂による寿命は $0.1 \sim 2 \mathrm{sec}$ と推定され，それが立証 されればこの元素の存在が確認できるわけである。そ こでかれらはその程度の自発核分裂の寿命を測定する

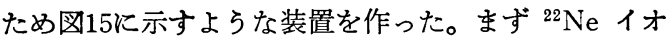
ンの照射によりターゲットで反応が起き，その反応生 成物が一定の速度で動いている $\mathrm{Ni}$ のベルトに飛び达 む。そのベルトの周囲には 105 個の飛跡検出器 (リン 酸ガラス）が置かれ，それらの核分裂片の飛跡を計数 することにより，その半減期および断面積が求まるわ けである。かくして得られた自発核分裂の寿命は 1.8 土0.6 $\mathrm{sec}$ で，生成元素を ${ }^{261} 105$ としたときの理論的推 定値とよく一致した ${ }^{61)}$ 。

固体飛跡検出器は一般的には上記のような短寿命の ものより長寿命の自発核分裂の測定に使用される。と くに地球上の物質のなかにも最近理論的にその存在を 予言されている超重核はすべて自発核分裂を起こしか つその寿命が比較的短いため，もしも地表の物質で化 学的性質の似ているもののなかに微量でも混入してお ればその自発核分裂を検出することによりその存在を 確認できるかも知れない。このよらな立場から $\mathrm{Pb}$, $\mathrm{Tl}, \mathrm{Bi}, \mathrm{Hg}, \mathrm{W}$ 等での自発核分裂の有無が各方面で調 べられている。このような目的には飛跡検出器は非常 に有効で二，三のグループによって測定が行なわれて いるが，いまのところそれらの物質の自発核分裂の寿 命の上限を与えているに止まっている62),63)。

\section{$4 \cdot 2$ 宇宙線および宇宙物理関係}

ここでは宇宙線および宇宙物理への応用として， 一次宇宙線中に含まれる $\mathrm{Fe}$ 以上の元素組成の測定, magnetic monopole の検出, 隕石および月面試料で の超重核存在の有無等の研究の現状について述べる。

固体飛跡検出器が見出されるまでは鼻一次宇宙線と 


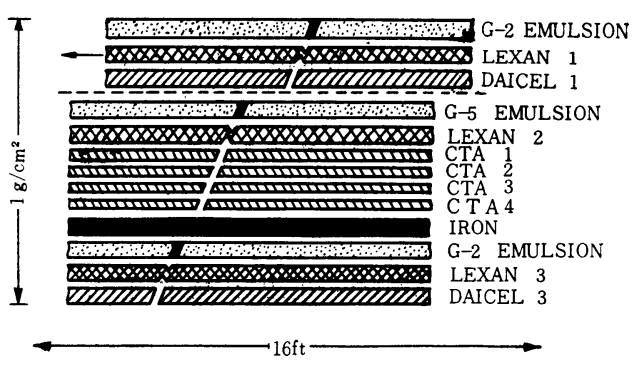

(A)

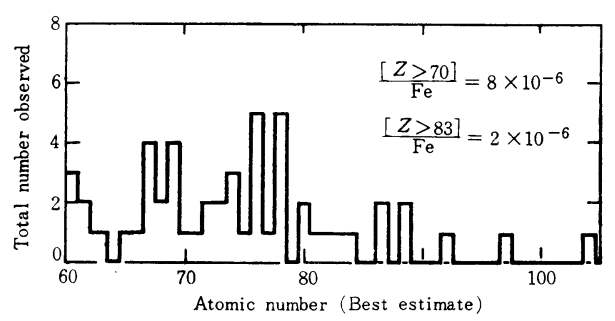

(B)

図16 （A）重一次荷電粒子測定用の（固体飛跡検 出器十原子核乾板) の typical stack

(B) $Z>60$ の重一次宇宙線の核電荷分布

くに Fe 以上の重粒子の検出にはほとんど原子核乾板 が使用されてきた。しかし宇宙線中の重粒子の強度は きわめてわずかで統計精度を上げょうとすればその検 出面積を広げねばならないが，原子核乾板はかなり高 価なためそう簡単に検出面積を飛躍的に増大するわけ には行かない。しかるに固体飛跡検出器はその価格は 原子核乾板よりはるかに安く重さも軽く, かつ重粒子 の核種弁別能力がすぐれているため, 重一次宇宙線の 検出に大々的に使用されるようになった。

最近まで, Price, Fleischer らは数種類の固体飛跡 検出器と原子核乾板とを積み重ねたものを気球に乗せ 気圧数 $\mathrm{mb}$ の上空へ飛ばし, 原子核乾板による測定結 果とを比較しながら固体飛跡検出器による結果を検討 してきた。その 1 例として相対論的速度領域にある重 荷電粒子検出用に使用されたものを図 16 亿示す ${ }^{60)}$ 。こ の場合固体飛跡検出器としてLexan(polycarbonate), CTA (cellulose triacetate), Daicel (cellulose nitrate)の 3 種類が使用されている。このうち Daicel は貫通せる重荷電粒子の位置を知るためにの及使用さ れ，残りの Lexan, CTAにより $v_{T}$ を測定して通過 粒子の核電荷をきめるわけである。また気球の上昇時 之降下時に入射する粒子の飛跡之水平飛跡時に入射せ るむのとを見分けることのできるように上昇，降下時 に下部の本体からずらすことができるようになってい
る。上部の G-2 emulsion + Lexan + Daicell は面積 こそ違えこのような装置をすでに 8 回も飛ばし，飛翔 時間 $\times$ 検出面積の総和はすでに $3,000 \mathrm{~m}^{2} \mathrm{~h}$ を越光てい る。しかし速度の推定が十分でなかったりしていまま での核電荷の推定にはかなり疑わしい点がある。たと 党ば原子核乾板から $Z \approx 105$ と推定されたものが固体 飛跡検出器では $Z \approx 92$ とでたりしている。戝16(B)は 1970年末までに発表された一次宇宙線に含まれた $Z>$ 60のデータをまとめたものであるが64)，以上のような 理由でこの分布がどの程度信頼できるものか疑問であ る。最近では粒子の速度の暧昧さを避けるために Cerenkov film と称する検出器を取りつけて, 粗いが一 応の速度の推定を行ならようになった ${ }^{65)}$ 。また昨年の 第12回宇宙線国際会議での報告によれば一昨年飛ばし た気球の解析結果として $Z=100 \pm 5$ の核電荷をもっ た粒子が検出されているが，これはいままでに固体飛 跡検出器で推定された最大の核電荷である ${ }^{66)}$ 。またそ の国際会議での Price の講演では最近約 $50 \mathrm{~m}^{2}$ もるる 固体飛跡検出器を気球で飛ばしたとのことである。

一方数百 $\mathrm{MeV} /$ nucleon 程度までの重一次宇宙線は $\tau^{\top} T-R$ 法によってかなり精度よく核種を弁別できるこ とは前にも述べた。図17は最近D. O'Sullivan, Price,

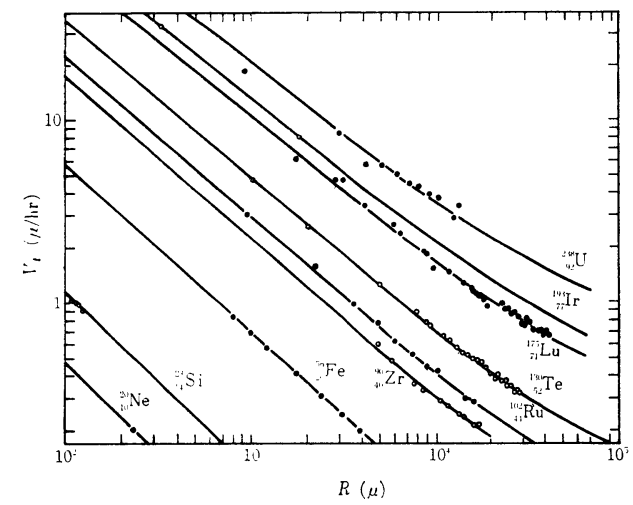

図17〜200 MeV/nucleon の重一次宇宙線によ り得られた重イオンの $v_{T}-R$ 曲線

Fowler によって Lexan を用いて得られた $\mathrm{Fe}$ 以上

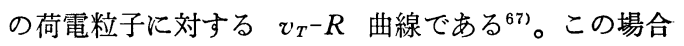
の精度 $\Delta Z / Z$ は原子核乾板で約 $3 \%$ あるあのに対し Lexanでは $1 \%$ であった。またそれぞれの方法で推定 された核電荷の差の平均は $0.9 \%$ で相対論的領域に おける $v_{T}$ のみによる核電荷の推定の場合よりも精度 がはるかによいことがわかった。

さてつぎに固体飛跡検出器が magnetic monopole 捜しに使用されている点に触れよう。周知のごとく 
magnetic monopole は初め Dirac によってその存在 の可能性を指摘された次式によって与えらる単一極の 磁荷をもった粒子のことである。

$$
g=n \hbar c / 2 e
$$

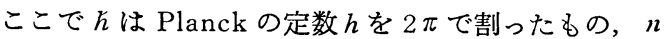
は任意の整数, $e$ は電荷の最小単位である ${ }^{68)}$ 。かかる 粒子の電離能力はその速度が周囲の原子を構成する電 子の速度より速ければ，(137/2)ne の電荷をもち相対 論的速度領域にある荷電粒子のそれと同等である。乙 かも高エネルギー加速器による magnetic monopole の実験でいずれも検出に成功していないことからその 質量は少なくとも陽子の 3 倍以上とされている699。乙 たがってもしも magnetic monopole が実在するもの とすれば，それは物質通過のさいに重荷電粒子と実質 的に同様な作用をすると考兄られる。かかる理由で固 体飛跡検出器が magnetic monopole_の検出に使用さ れるわけである。

一方10年ほど前 Porterによって一次宇宙線の超高 エネルギー $\left(>10^{17} \mathrm{eV}\right)$ 領域に括ける主成分は magnetic monopole であることの可能性を指摘されてか $5^{70)}$, 各方面で宇宙線中の magnetic monopole の検 出が試みられるようになった。最近の Fleischer らに よる固体飛跡検出器を使用した一連のmagnetic monopole 捜しもかかる試みの 1 つである ${ }^{71) ~ 74) 。 そ の う ~}$ ち最る簡単な方法は地表に降ってくる超高エネルギー の magnetic monopole（エネルギーが高いためその 強度は大気中でほとんど減衰しない）を広い面積をも つ固体飛跡検出器を長時間広げ, magnetic monopole による飛跡の観測を行ならもので, Fleischer らによ って行なわれている74)。いずれも magnetic monopole の検出には成功せず，その上限を与えるに止ま っているが，従来の方法に比しかなりの感度を上げる ことができるのでこの方面での記録を更新しつつある といらのが現状である。

先に述べた超重核 $(Z \gtrsim 110)$ が宇宙物質中に存在 するか否かは宇宙物理学的見地からも非常に興味ある 問題である。かかる超重核の核分裂エネルギーは 200 $\mathrm{MeV}$ 以上で ${ }^{235} \mathrm{U},{ }^{238} \mathrm{U}$ の值 $(\sim 170 \mathrm{MeV})$ に比して 大きく，したがってその物質中における核分裂片の飛 程も15 30\% も長い。かくして宇宙物質中での核分裂 片の飛程分布から超重核存在の有無を験証することが 可能である。Price, Fleischer は隕石中の核分裂片 の飛程分布の測定から超重核の存在に対して否定的な 結論を得た ${ }^{75)}$ 。一方 Bhandari, Bhat, Lal らは隕石 や月物質中での核分裂片の飛程分布をかれらが独自に
開発した TINT 法や TINCLE 法を用いて測定し, 超重核によると思われる飛跡を見出している76)。しか しまだ実験上問題の点もあり，この結果に対して疑念 をもっている人が多い上うである。

\section{$4 \cdot 3$ 原子力関係}

ここでは中性子計測への応用を中心に述べ，原子炉 計測や $\alpha$ 線に対する新しい利用面についても触れる。

固体飛跡検出器では中性子と検出器の材料を構成す る原子の核との弾性散乱による反跳核や核反応により 生成される重イオンの飛跡を検出することによって中 性子の測定を行ならことができる。有機物質の場合に はこれらが混合して拈りその中性子に対する response function は結構複雑である。しかしその中性子検 出のしきい值は Makrofol E (polycarbonate) の場 合でも $E_{n}=1.2 \mathrm{MeV}$ (これはCの反跳核によってき まる)で77，そのまま速中性子の検出器として使用で きる。ガラスのような無機物質の場合には飛跡生成の 感度が低いのでむしろ意識的に核分裂性物質を混入し

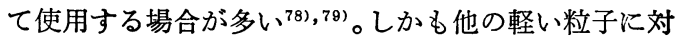
する感度が低いため，比較的明確にその response function を設定できる。筆者らはこの点に着眼して 各種の核分裂性物質を dope したガラス飛跡検出器を 組み合わせ一種の threshold detector として使用し，

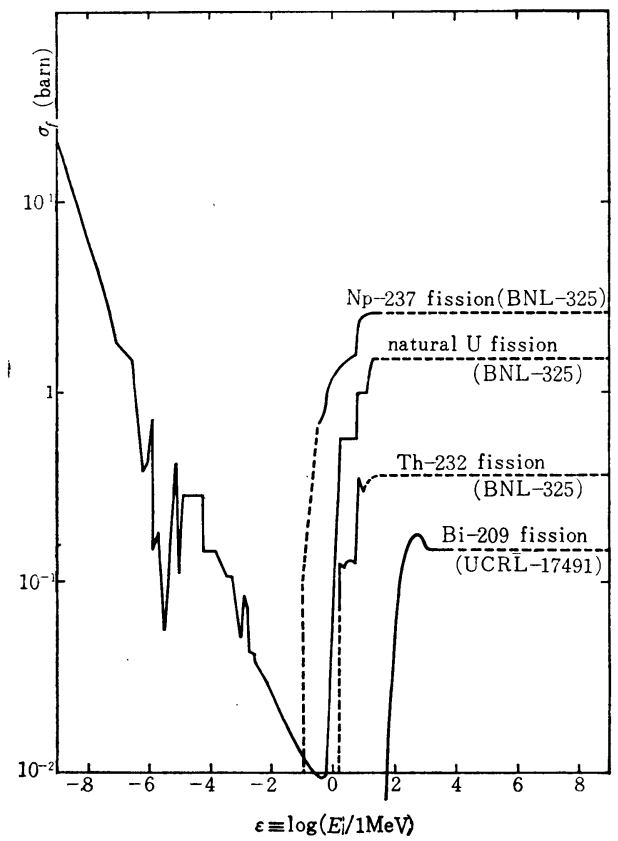

図18 ${ }^{237} \mathrm{~Np}$, natural U, ${ }^{232} \mathrm{Th},{ }^{209} \mathrm{Bi}$ の中性子 のエネルギーに対する核分裂断面積の関係 


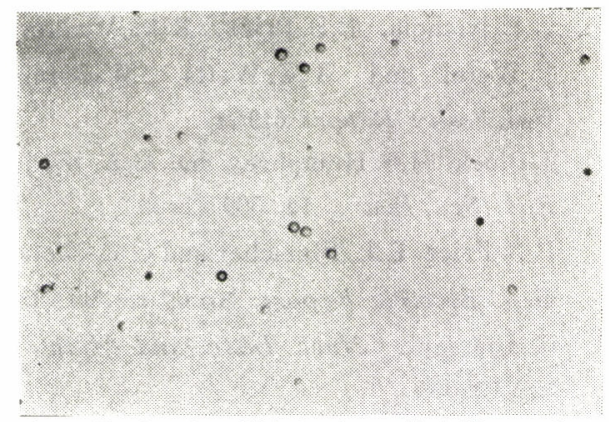

図19 $\mathrm{Bi}_{2} \mathrm{O}_{3}$ を50\%含むガラス検出器に拈ける $\mathrm{Bi}$-fission の飛跡

中性子束のエネルギー分布の測定や線量測定に用いる ことを検討している。図18はいま筆者らが考光ている 核分裂性物質の中性子ェネルギーに対する反応断面積 の曲線を示す。これらのららすでにU, $\mathrm{Th}^{78)}, \mathrm{Bi}^{79)}$ dope したガラス飛跡検出器が製作されて和り, 近く ${ }^{237} \mathrm{~Np}$ をdope したものもできる予定である。図19に $\mathrm{Bi}_{2} \mathrm{O}_{3}$ を $50 \%$ dope したガラス検出器を東大原子核 研究所の $1.3 \mathrm{GeV}$ 電子シンクロトロンの近傍に置い て検出した核分裂片の飛跡を示す。らえに述べたよう な飛跡検出器と中性子に対する threshold detector として利用する試みは他にもあるが80), いずれも有機 物質の表面に核分裂性物質を蒸着ないしは電着するも のでと゚らしても感度が低いものしかできないといら欠 点を伴らが, ガラス検出器ではかなりの量の核分裂性 物質が dope できるとともに図19に示すよらに核分裂 片の飛跡は球形で計数上きわめてつごらがよいという 特徵をもつので今後の発展が大いに期待される。また 最近低エネルギー領域での中性子検出器としてB入り の cellulose nitrate も開発されている811。

一方固体検出器は $\gamma, \beta$ 線等の強いパックグラウン ドの状態でも核分裂片が確実に検出できること，検出 器自体としては小型で少量ですむこと和よび周囲の環 境に対して長期間安定なこと等のため原子炉内での ${ }^{238} \mathrm{U} /{ }^{235} \mathrm{U}$ の核分裂比の測定 ${ }^{82), 83)}$ や炉心部の中性子温 度の測定 ${ }^{84)}$ に使用されている。

中性子以外に, 固体飛跡検出器は $\alpha$ 粒子検出用に使 用されることが多い。そのなかで特徵あるものとして は Rn および Rn-daughters による lung dose 推 定用の monitorとしての利用や85186), 骨の中の $\alpha$ 放射 能に対する radiography 等 ${ }^{87) を あ け ゙ る こ と か ゙ て ゙ き よ ~}$ う。とくに後者に関しては最近 Somogyi, Srivastava により $\alpha$-radiography のための基礎研究が行なわれ たことが目を引く ${ }^{88)}$ 。

また Frank, Benton は $10^{7} \mathrm{rad}$ 以上の $\gamma$ 線の照射
を受けた有機物質の bulk な etching speed $v_{G}$ が照 射を受けていない場合よりもかなり増大することか ら, $v_{\theta}$ の変化の測定により $10^{7} \sim 10^{9} \mathrm{rad}$ の軟X線や $\gamma$ 線による吸収線量を推定することを試みている ${ }^{891}$ 。

紙数も尽きたので最後に前にも述べた Apollo 8 号 および12号の宇宙飛行士のへルメットに和ける重イオ ン粒子の飛跡から得られた情報に基ついて，それら重 イオンによる宇宙飛行士の受ける生物学的損傷の推定 が Comstock, Fleischer, Giards らにより行なわれ ている(9)ことを述べて䇠をおくことにする。

\section{文献}

1) 坂上正信: Radioisotopes, 17, 212 (1968)

2）道家忠義：応用物理, 38, 1065 (1969)

3) R.L.Fleischer, P.B.Price, R.M. Walker and E.L.Hubbard: Phys. Rev., 156, 353 (1967)

4) H.A. Bethe: Ann. Physik, 5, 325 (1930)

5) H.H.Heckman, B.L.Perkins, W.G.Simon, F.M.Smith and W.M. Barkas: Phys. Rev., 117, 544 (1960)

6) R. Katz and E.J.Kobetich: Phys. Rev., 170, 401 (1968)

7) P.B. Price and R.M.Walker: J. Appl. Phys., 33, 3407 (1962)

8) E.V.Benton: USRDL-TR-68-14 (1968)

9) E.V.Benton and W.D.Nix: Nucl. Instr. and Meth., 67, 343 (1969)

10) W.H.Barkas: Nuclear research emulsion (Academic Press, New York, 1963)

11) E.V.Benton and R.P. Henke: Nucl. Instr. and Meth., 67, 87 (1969)

12）道家忠義：原研・理研共催「重イオン研究会」 12月 1 日 (1971)

13) W.D. Jones and R.V. Neidigh: Appl. Phys. Letters, 10, 18 (1967)

14) P.B.Price, D.D. Peterson, R.L. Fleischer, C. O'Ceallaigh, D. O'Sullivan and A. Thompson: Canad. J. of Phys., 46, S1149 (1968)

15) M. Varnagy, J. Csikai, S. Szegedi and S. Nagy: Nucl. Instr. and Meth., 89, 27 (1970)

16) W.H.Huang and R.M. Walker: Science, 155, 1103 (1967) 
17) S. Katcoff: Science, 166, 382 (1969)

18) K. Becker: Radiation Res., 36, 107 (1968)

19) R.H. Boyett, D.R. Johnson and K. Becker: Radiation Res., 42, 1 (1970)

20) P.B.Price and R.L.Fleischer: Gen. Electric Report, No. 69-C-216 (1969)

21) W.T.Crawford, W. DeSorbo and J.S. Humphrey: Nature, 220, 1313 (1968)

22) E.V.Benton and R.P.Henke: Nucl. Instr. and Meth., 70, 183 (1969)

23) W. DeSorbo and J.S. Humphrey: Radiation Effects, 3, 281 (1970)

24) H.Crannell, C.J. Crannell and F.J. Kline: Science, 166, 606 (1969)

25) C.J.Crannell, H.Crannell and C.O'Sullivan: IEEE, Nucl. Sci., NS-17, 337 (1970)

26) C.R. Srinivasan, S. Younger, P.B. Macedo and T.A.Litovitz: Phys. Rev. Letters, 27, 1084 (1971)

27) D.D. Peterson: Rev. Sci. Instr., 41, $12 \overline{5} 4$ (1970)

28) G. Somogyi, M. Várnagy and G. Petö: Nucl. Instr. and Meth., 59, 299 (1968)

29) D. Lal: Space Science Reviews, 9, 623 (1969)

30) N. Bhandari, S.G. Bhat, D. Lal, G. Rajagopalan, A.S. Tamhane and V.S. Venkataradan: Nature, 230, 219 (1971)

31) E.V.Benton: Nucl. Instr. and Meth., 92, 97 (1971)

32) W.W.Schultz: Rer. Sci. Instr., 39, 1893 (1968)

33) P.Pellas, G. Poupeau, J.C. Lorin, H. Reeves and J. Audouze: Nature, 223, 272 (1969)

34) D. Jowitt: Nucl. Instr. and Meth., 92, 37 (1971)

35) N.L. Lark: Nucl. Instr. and Meth., 67, 137 (1969)

36) W.G.Cross and L. Tommasino: Health Phys., 13, 932 (196\%); L. Tommasino and W.G.Cross: ibid., 15, 196 (1968)

37) D.R. Johnson, R.H. Boyett and K.Becker: ibid., 18, 424 (1970)

38) G.E. Blanford, R.L. Fleischer, P.H. Fowler, M.W. Friedlander, J. Klarmann, J.M. Kidd,
G.E. Nichols, P.B. Price, R.M. Walker, J. P.Wefel and W.C.Wells: Washington University Report (1969)

39) J.Block, J.S. Humphrey and G.E. Nichols: Rev. Sci. Instr., 40, 509 (1969)

40) P.B. Price, R.L. Fleischer and G.E. Nichols: Gen. Electric Report, No.69-C-300 (1969)

41) G.Somogyi: Nucl. Instr. and Meth., 42, 312 (1966)

42) U.Höpper, E. Konecny and G.Fiedler: Nucl. Instr. and Meth., 74, 285 (1969)

43) R.L.Fleischer, P.B. Price and R.T. Woods: Phys. Rev., 188, 563 (1969)

44) E.V.Benton and R.P. Henke: Nucl. Instr. and Meth., 58, 241 (1968)

45) R.L. Fleischer, P.B. Price, R.M. Walker, M. Maurette and G. Morgan: J. Geophys. Res., 72, 355 (1967)

46) P.B.Price, R.L. Fleischer and C.D. Meak: Phys. Rev., 167, 277 (1968)

4\%) P.B. Price, R.L. Fleischer, D.D. Peterson, C. O'Ceallaigh, D. O'Sullivan and A. Thompson: Phys. Rev., 164, 1618 (1967)

48) P.B. Price, R.L. Fleischer, D.D. Peterson, C. O'Ceallaigh, D. O'Sullivan and A. Thompson: Phys. Rev. Letters, 21, $630^{\circ}$ (1968)

49) R.L. Fleischer, H.R. Hart and W.R. Giard: Science, 170, 1189 (1970)

50) P.B.Price, R.L. Fleischer and G.E. Nichols: Gen. Electric Report, 69-C-300(1969); R.L. Fleischer, G.E. Nichols and P.B. Price: Phys. Rev. Letters, 23, 338 (1969)

51) D. O'Sullivan, E.J. Kobetich, E.K.Shirk and P.B.Price: Physics Letters, 34B, 49 (1971)

52) M.Ait-Salem, H.Gerhardt, F.Gönnenwein, H. Hipp and H. Paap: Nucl. Instr. and Meth., 60, 45 (1968)

53）道家忠義, 遠藤有声, 岡本肇: 宇宙線研究, 16, 93 (1971)

54) J. Hudis and S. Katcoff: Phys. Rer., 180, 1122 (1969)

55) M. Debeauvais, R. Stein, J. Ralarosy and P. Cüer: Nucl. Phys., A90, 186 (1967) 
56) R. Brandt, F. Carbonara, E. Cieslak, M. Dakowski, Ch. Gfeller, H. Piekarz, J. Piekarz, W. Riezler, R. Rinzinillo, E. Sassi, M. Sowinski and J.Zakrazewski: Nucl. Phys., A70, 177 (1967)

57) G. Rémy, J. Ralarosy, R. Stein, M. Debeauvais and J. Tripier: Proc. Int. Conf. Nuclear Track Registration in Insulating Solids, Clermont-Ferrand (1969)

58) G. Rémy, J. Ralarosy, R. Stein, M. Debeauvais and J.Tripier: Nucl. Phys., A163, 581 (1971)

59) R. Brandt, F. Carbonara, E. Cieslak, H. Piekarz, J.Piekarz and J.Zakrazewski: CERN Report 71-2 (1971)

60) H. Annoni, A. Cordaillat, A.J. Herz O. Mendola and R. Oppel: CERN Report 70-27 (1970)

61) G.N. Flerov, Yu Ts. Oganesian, Yu. V. Lobanov, Yu. A. Lasarev, S.P.Tretiakova, I.V. Kolesov and V.M. Platko: Nucl. Phys., A160, 181 (1971)

62) G.N.Flesov and W.P. Perelygin: At. Energ., 26, 520 (1969)

63) P.B. Price, R.L. Fleischer and R.T. Woods: Phys. Rev. C., 1, 1819 (1970)

64) P.B.Price, P.H. Fowler, J.M. Kidd, E.J. Kobetich, R.L. Fleischer andG .E. Nichols: Phys. Rev. D, 3, 815 (1971)

65) L.S. Pinsky, R.D. Eandi, W.Z. Osborne and R.B. Rushing: Proc. 12th Int. Conf. on CosmictRays, 3, 1630 (1971)

66) E.J. Kobetich, P.B. Price, E.K. Shirk, R.D. Eandi, W.Z. Osborne, L.S. Pinsky and R. B. Rushing: Proc. 12th Int. Conf. on Cosmic Rays, 1, 1792 (1971)

67) D. O'Sullivan, P.B. Price, E.K. Shirk, P.H. Fowler, J.M.Kidd, E.J.Kobetich and R. Thorne: Phys. Rev. Letters, 26, 463(1971)

68) P.A.M. Dirac: Proc. Roy. Soc., A133, 60 (1931); Phys. Rev., 74, 817 (1948)

69) R.L.Fleischer, H.R. Hart, I.S. Jacobs, P. B. Price, W.M.Schwarz and R.T.Woods: J. Appl. Phys., 41, 958 (1970)
70) N.A.Porter: Nuovo Cimento, 16, 958(1960)

71) R.L. Fleischer, H.R. Hart, I.S. Jacobs, P.B. Price, W.M. Schwarz and F.Aumento: Phys. Rev., 184, 1393 (1969)

72) R.L. Fleischer, P.B. Price and R.T. Woods: Phys. Rev., 184, 1398 (1969)

73) R.L.Fleischer, I.S. Jacobs, W.M.Schwarz, P.B. Price and H.G. Goodell: Phys. Rev., 177, 2029 (1969)

74) R.L.Fleischer, H.R. Hart, G.E. Nichols and P.B.Price: Phys. Rev., D, 4, 24 (1971)

75) P.B. Price and R.L. Fleischer: Phys. Letters, 20B, 246 (1969)

76) N. Bhandari, S.G. Bhat, D. Lal, G. Rajagopalan, A.S. Tamane and V.S. Venkatavaradan: Nature, 230, 219 (1971)

77) K. Józefowicz: Nucl. Instr. a id Meth., 93, 369 (1971)

78) R. Yokota, S. Nakajima and Y. Muto: Nucl. Instr. and Meth., 61, 119 (1968)

79) K. Katoh and T. Doke: SJC-A-69-7 (1969)

80) G.D.Kerr: ORNL-TM-2120

81) W.W.Schultz: J. Appl. Phys., 41, 5260 (1970)

82) C.B.Besant: J. Nucl. Energy, 24, 59 (1970)

83) D. Jowitt: Nucl. Instr. and Meth., 92, 37 (1971)

84) C.S.Su and T.C.Liu: Nucl. Instr. and Meth., 89, 233 (1970)

85) D.B. Lovett: Health Phys., 16, 923 (1969)

86) K. Becker: Health Phys., 16, 113 (1969)

87) A.Cole, D.J.Simmons, H.Cummins, F.J. Congel and J. Kastner: Health Phys., 19, 55 (1970)

88) G. Somogyi and D.S. Srivastava: Int. J. Appl. Rad. and Isotopes, 22, 289 (1971)

89) A.L.Frank and E.V.Benton: Proc. Int. Conf. Nuclear Track Registration in Insulating Solids, Clermont-Ferrand (1969)

90) G.M. Comstock, R.L. Fleischer, W.R. Giard, H.R.Hart, G.E. Nichols and P.B. Price: Science, 172, 154 (1971) 